\title{
Pathways of glutamate catabolism among Fusobacterium species
}

\author{
Saheer E. Gharbia* and Haroun N. Shah \\ Department of Oral Microbiology, The London Hospital Medical College, London EI 2AD, UK
}

(Received 15 October 1990; revised 14 January 1991; accepted 17 January 1991)

\begin{abstract}
Glutamate is a major source of energy for Fusobacterium species but its mode of catabolism has not hitherto been elucidated. Cell suspensions of $\boldsymbol{F}$. nucleatum and $\boldsymbol{F}$. varium, as representative species from the oral cavity and gastrointestinal tract, respectively, both decarboxylated position-labelled glutamate but by different pathways. ${ }^{14} \mathrm{CO}_{2}$ was released only from $\mathrm{C}-5$ by $F$. nucleatum whereas $F$. varium decarboxylated glutamate at either $\mathrm{C}-1$ or C-5. In both species, 2 mols of glutamate fermented yielded 2 mols of acetate and $1 \mathrm{~mol}$ of butyrate, suggesting the possibility of three metabolic pathways: the 2-oxoglutarate, mesaconate and 4-aminobutyrate pathways. Enzymes representative of the three pathways were assayed for in cell-free extracts of fusobacteria. All species tested possessed high levels of both glutamate dehydrogenase and 2-oxoglutarate reductase, indicating the presence of the 2-oxoglutarate pathway. Enzymes representative of the mesaconate pathway were detected in F. sulci, F. ulcerans, $F$. mortiferum and $F$. varium, while the latter two species also possessed the 4-aminobutyrate pathway. The pathways of glutamate catabolism therefore bore no relationship to the site of isolation of the fusobacteria tested but instead correlated with their chemotaxonomic properties. Thus, $F$. varium, $F$. mortiferum, $F$. ulcerans and $F$. sulci, which possess a peptidoglycan structure based on diaminopimelic acid, have either two or three pathways for glutamate catabolism whereas $\boldsymbol{F}$. nucleatum and other species that have a lanthionine-based murein metabolized glutamate solely by the 2-oxoglutarate pathway.
\end{abstract}

\section{Introduction}

Fusobacterium species colonize the mucous membranes of man and animals and are now regarded as important opportunistic pathogens (Moore et al., 1984). Their successful colonization and survival is probably influenced by their ability to utilize substrates effectively at these sites. Previous studies have so far revealed that carbohydrates, as energy sources, are poorly utilized and their fermentation is limited to only a few species such as $F$. varium (Gharbia \& Shah, 1988b). Species were shown to assimilate $30-100 \%$ of the available glucose in the medium (Gharbia \& Shah, 1988), but $\left[{ }^{14} \mathrm{C}\right]$ glucose incorporation experiments revealed that this is used for the biosynthesis of various cellular components (Gharbia \& Shah, 1989b) and storage glycopolymers (Robrish et al., 1987). The latter can, however, be metabolized in the absence of other fermentable substrates (Robrish \& Thompson, 1988).

Peptides, supplied as protein hydrolysates (Gharbia \& Shah, 1988) and amino acids (Gharbia \& Shah, 1989; Gharbia et al., 1990; Shah \& Gharbia, 1989) comprise the major sources of energy for all Fusobacterium species.
Among the amino acids used, acidic (anionic) and basic (cationic) monomers, particularly glutamate, are taken up at high concentrations. Furthermore, amino acid uptake profiles are significantly altered by incorporating high levels of glutamate in the culture medium. These observations, together with the fact that glutamate constitutes more than $50 \%$ of the pool of free amino acids in human dental plaque (Singer \& Kleinberg, 1983), suggest that this amino acid is likely to be a major source for $F$. nucleatum in vivo. Preliminary results indicated that there might be significant differences in the method by which glutamate is catabolized by Fusobacterium species. In the present study we therefore determined the pathway by which glutamate is catabolized by Fusobacterium species using enzyme assays, experiments with radio-labelled glutamate and metabolic end-product determinations. Species which generally colonize the oral cavity (e.g. F. nucleatum, $F$. alocis, $F$. periodonticum and $F$. sulci), the gastrointestinal tract (e.g. $F$. varium, $F$. gonidiaformans, $F$. mortiferum and $F$. necrogenes), the skin (e.g. F. ulcerans) and others which are frequently isolated from animals (e.g. F. russii and F. necrophorum) were tested. 


\section{Methods}

Bacterial strains and cultivation. The following strains were used: $F$ nucleatum, ATCC 25586; F. alocis, ATCC 3364; F. gonidiaformans, ATCC $25563 ; F$. naviforme, NCTC 25832; $F$. necrophorum, NCTC $10575, F$. necrogenes, A TCC $25556 ; F$. periodonticum, ATCC $33693 ; F$. russii, ATCC $25533 ; F$. sulci, ATCC $35585 ; F$.ulcerans, NCTC 12111 $F$. varium, VPI 0499A ; and $F$. mortiferum, NCTC 25557. All strains were maintained by weekly subculture on $2 \cdot 5 \%(\mathrm{v} / \mathrm{v})$ blood agar plate, in an atmosphere of $10 \%(\mathrm{v} / \mathrm{v}) \mathrm{CO}_{2}$ and $5 \%(\mathrm{v} / \mathrm{v}) \mathrm{H}_{2}$ in $\mathrm{N}_{2}$ at $37^{\circ} \mathrm{C}$.

Determination of glutamate fermentation pathways with $\left[{ }^{1+} \mathrm{C}\right] \mathrm{gluta}$ mate. $F$. nucleatum and $F$. varium strains were used as representative species. Both were grown in a medium containing $(\%, w / v):$ glucose, 0.5 ; yeast extract, $0.5 ;$ trypticase, $1.0 ; \mathrm{NaCl}, 0.5 ;$ and sodium thioglycollate, $0 \cdot 1$. Cells were harvested after $24 \mathrm{~h}$ by centrifugation at $10000 \mathrm{~g}$ for $15 \mathrm{~min}$, and washed twice in phosphate-buffered saline ( $50 \mathrm{~mm}$ potassium phosphate containing $0.85 \% \mathrm{NaCl}$ ), $\mathrm{pH} 7 \cdot 5$, under anaerobic conditions. Fermentation experiments were done with cell suspensions prepared by resuspending the washed cells at 80-100 times the concentration in the original culture in $\mathrm{O}_{2}$-free $50 \mathrm{~mm}$-potassium phosphate buffer ( $\mathrm{pH} 7 \cdot 0$ ) containing $0.1 \%$ sodium thioglycollate. Samples $(0.5 \mathrm{ml})$ of such cell suspensions were incubated with sodium $\left[1-^{14} \mathrm{C}\right]-$ or $\left[5^{-1+} \mathrm{C}\right]$ glutamate $(20 \mu \mathrm{mol} ; 370 \mathrm{kBq})$ in a total volume of $2 \mathrm{ml}$ in tubes stoppered with vaccine caps under an atmosphere of $\mathrm{N}_{2}$. Durham tubes containing hyamine hydroxide were placed in each $\mathrm{O}_{2}$ free tube to trap released $\mathrm{CO}_{2}$. All tubes and reagents were held at $37^{\circ} \mathrm{C}$ prior to and after initiating the reactions. At $30 \mathrm{~min}$ intervals, one reaction mixture was stopped by the addition of $1 \mathrm{M}-\mathrm{HCl}(100 \mu \mathrm{l})$, and the tube was allowed to stand for $30 \mathrm{~min}$ at room temperature. The Durham tube was then removed and the exterior was rinsed thoroughly with distilled water and the tube and contents were placed in a scintillation vial containing $6 \mathrm{ml}$ of the scintillation fluid Cocktail $\mathrm{T}$ $(\mathrm{BDH})$. The cell suspension itself was centrifuged and to $1 \mathrm{ml}$ of the supernatant, $2 \mathrm{ml}$ methanol and $0.5 \mathrm{ml} 50 \%(\mathrm{v} / \mathrm{v}) \mathrm{H}_{2} \mathrm{SO}_{4}$ were added. The contents were mixed and held at $50{ }^{\circ} \mathrm{C}$ for $30 \mathrm{~min}$, after which $1 \mathrm{ml}$ of distilled water and $0.5 \mathrm{ml}$ chloroform were added to the mixture, and the contents centrifuged at $1000 \mathrm{~g}$ for $10 \mathrm{~min}$. The chloroform layer was withdrawn, and mixed with $6 \mathrm{ml}$ of the scintillation fluid, and the samples counted in a model SL30 liquid scintillation counter (Intertechnique, UK).

Determination of enzyme activities. Cell-free extracts, prepared as described previously (Gharbia \& Shah, 1988a) were centrifuged at $20000 \mathrm{~g}$ for $15 \mathrm{~min}$ to remove the particulate fraction. The supernatants were kept in sealed vials under an $\mathrm{O}_{2}$-free atmosphere of $\mathrm{N}_{2}$ at $4{ }^{\circ} \mathrm{C}$, and assayed as quickly as possible to ensure minimal loss of activity. All assays were completed the same day, and substrates used were freshly prepared. All assays were done at $25^{\circ} \mathrm{C}$ using a Gilford model 240 spectrophotometer. The Lowry procedure was used for protein estimation with bovine serum albumin fraction V (Sigma) as standard. All substrates were from Sigma unless otherwise stated.

2-oxoglutarate reductase (EC 1.1.99.2). 2-Oxoglutarate reductase activity was determined spectrophotometrically by following changes in absorbance at $340 \mathrm{~nm}$. The reaction mixture for assaying enzymic reduction of 2-oxoglutarate contained the following components: $0.5 \mathrm{~mm}$-potassium phosphate buffer, $\mathrm{pH} 7.5,10 \mathrm{~mm}-\mathrm{NADH}$, and $100 \mu \mathrm{l}$ or $50 \mu \mathrm{l}$ of cell extract. The reaction was initiated with $100 \mu \mathrm{l}$ $7.5 \mathrm{~mm}$-2-oxoglutarate, in a total volume of $1 \mathrm{ml}$. The $\mathrm{pH}$ optimum for 2-oxoglutarate was determined over the $\mathrm{pH}$ range of 5-11. The Michaelis constant was estimated for the above reaction mixture using increasing concentrations of 2-oxoglutarate $\left(9.3 \times 10^{-6}-6 \times 10^{-4} \mathrm{M}\right)$. Interference from glutamate dehydrogenase, activity was minimized by ensuring that $\mathrm{NH}_{4}^{+}$was eliminated from the reaction mixture.
The reverse reaction was measured in a reaction mixture containing $0 \cdot 1 \mathrm{M}$-Tris/ $\mathrm{HCl}, \mathrm{pH} 8.5 ; 10 \mathrm{~mm}$-2-hydroxyglutarate, $100 \mu \mathrm{l} ; 10 \mathrm{~mm}-$ $\mathrm{NAD}^{+}, 100 \mu \mathrm{l} ; 0.1 \mathrm{M}$-freshly neutralized hydroxylamine, $50 \mu \mathrm{l}$; and $50 \mu \mathrm{l}$ of cell extract, in a total of $1 \mathrm{ml}$.

Glutamate dehydrogenase (EC 1.4.1.2). Glutamate dehydrogenase activity was measured by following changes in absorbance at $340 \mathrm{~nm}$, both in the direction of glutamate oxidation and in the direction of glutamate synthesis. Optimal $\mathrm{pH}$ values for these reactions were determined. In the oxidation assay the following mixture was used: $0.1 \mathrm{M}$-Tris $/ \mathrm{HCl}$ buffer, pH $8.5 ; 40 \mathrm{~mm}$-glutamate, $100 \mu \mathrm{l} ; 10 \mathrm{~mm}$ $\mathrm{NAD}^{+}, 100 \mu \mathrm{l}$; and $50 \mu \mathrm{l}$ of cell extract, in a total volume of $1 \mathrm{ml}$. The formation of glutamate from 2-oxoglutarate was determined in a reaction mixture containing $0.1 \mathrm{M}-\mathrm{Tris} / \mathrm{HCl}$ buffer, $\mathrm{pH} 7.0 ; 0.5 \mathrm{M}$ $\mathrm{NH}_{4} \mathrm{Cl}, 50 \mu \mathrm{l} ; 40 \mathrm{~mm}$-2-oxoglutarate, $100 \mu \mathrm{l} ; 10 \mathrm{~mm}-\mathrm{NADH}, 100 \mu \mathrm{l}$; and $50 \mu \mathrm{l}$ of cell extract.

Reaction rates for 2-oxoglutarate reductase and glutamate dehydrogenase were corrected for NADH oxidase activity by subtracting the reaction rate observed in reaction mixtures before the addition of the $\mathrm{C}_{5}$-substrates. One unit of enzyme activity was defined as the amount of enzyme that catalysed the oxidation of $1 \mu \mathrm{mol} \mathrm{NADH} \mathrm{min}^{-1}$ or the reduction of $1 \mu \mathrm{mol} \mathrm{NAD}^{+} \mathrm{min}^{-1}$. Specific activity was defined as the amount of substrate (in $\mu \mathrm{mol}$ ) converted $\min ^{-1}$ (mg protein) $)^{-1}$.

3-Methylaspartase (EC 4.3.1.2). 3-Methylaspartase was measured by following the conversion of 3-methylaspartate to mesaconate, which results in the formation of a double bond and therefore an increase in absorbance at $240 \mathrm{~nm}$. The $\mathrm{pH}$ optimum for the reaction was determined, then the Michaelis constant was estimated using the

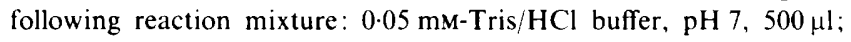
$150 \mathrm{~mm}-\mathrm{KCl}, 60 \mu \mathrm{l} ; 15 \mathrm{~mm}-\mathrm{MgCl}_{2}, 60 \mu \mathrm{l}$; and $100 \mu \mathrm{l}$ of cell extract. The reaction was initiated by the addition of sodium-L-threo$\beta$-methylaspartate at a concentration ranging from $0 \cdot 1 \times 10^{-6}$. $24 \times 10^{-4} \mathrm{M}$. One unit of enzyme activity was defined as the amount of enzyme required to catalyse an increase in $A_{240}$ of $0.04 \mathrm{~min}^{-1}$, equivalent to $1.039 \times 10^{-2} \mu \mathrm{mol}$ mesaconate $\mathrm{min}^{-1}$ (Barker et al, 1958).

4-Hydroxybutyrate dehydrogenase (EC 1.1.1.6I). This enzyme was assayed by following the reduction of $\mathrm{NAD}^{+}$at $340 \mathrm{~nm}$. The $\mathrm{pH}$ optium for 4-hydroxybutyrate oxidation was determined over the range $\mathrm{pH} 6-10 \cdot 5$, in the following reaction mixture: $0.1 \mathrm{M}$-Tris/ $\mathrm{HCl}$ buffer,

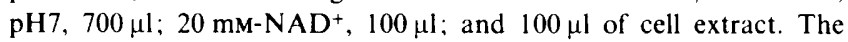
reaction was initiated with $100 \mu 120 \mathrm{~mm}$-4-hydroxybutyrate. The Michaelis constant was estimated in the above reaction mixture at $\mathrm{pH} 6.5$ using 4-hydroxybutyrate concentrations ranging from $3 \times 10^{-5}$ $8 \times 10^{-3} \mathrm{M}$. Specific activity is expressed as described for glutamate dehydrogenase.

Acetyl-CoA hybroxybutyrate-COA transferase. This enzyme was assayed by monitoring the increase in absorbance at $365 \mathrm{~nm}$ due to a complex reaction leading to the formation of crotonyl-CoA. The reaction mixture consisted of $0 \cdot 1 \mathrm{M}-\mathrm{Tris} / \mathrm{HCl}$ buffer, $\mathrm{pH} 5 \cdot 11.5$; $78 \mathrm{~mm}$-cysteine, $50 \mu \mathrm{l} ; 10 \mathrm{~mm}$-ATP, $50 \mu \mathrm{l} ; 2.6 \mathrm{~mm}$-coenzyme A, $50 \mu \mathrm{l}$; and $100 \mu \mathrm{l}$ of cell extract in a total of $1 \mathrm{ml}$. The reaction was initiated with 4-hydroxybutyrate using separately a series of concentrations ranging from $1.4 \times 10^{-6}-7 \times 10^{-4} \mathrm{M}$.

Acid end-product analysis. Volatile and non-volatile fatty acid endproducts of metabolism were analysed by GLC as described previously (Shah et al., 1976).

\section{Results}

\section{Glutamate fermentation pathways in $F$. nucleatum and} F. varium

The fermentation of glutamate by both $F$. nucleatum and $F$. varium yielded butyrate and acetate as the only acidic 

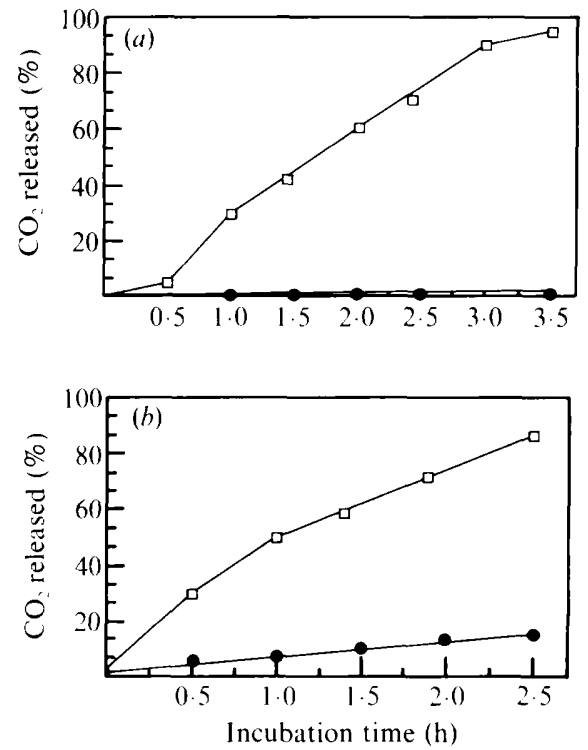

Fig. 1. Percentage release of ${ }^{1+} \mathrm{CO}_{2}$ from $\left[1^{-1+} \mathrm{C}\right]-(0)$ and $[5-1+\mathrm{C}]-(\square)$ glutamate by cell-suspensions of $F$. nucleatum $(a)$ and $F$. varium (b).

end-products. Both strains produced 2 mols of acetate and $1 \mathrm{~mol}$ of butyrate per 2 mols of glutamate added. When $\left[5-{ }^{1+} \mathrm{C}\right]$ glutamate was used as the substrate, over $95 \%$ of the total radioactivity was recovered in the $\mathrm{CO}_{2}$ liberated by $F$. nucleatum, and $86 \%$ by $F$. varium. However, when similar experiments were done with $\left[1^{14} \mathrm{C}\right]$ glutamate, only $0.3 \%$ of the radioactivity was found in the $\mathrm{CO}_{2}$ released by $F$. nucleatum and $14.6 \%$ by $F$. varium. The decarboxylation of all the $\left[{ }^{14} \mathrm{C}\right]$ glutamate added to a cell suspension of $F$. nucleatum required $3.5 \mathrm{~h}$ for completion, while $F$. varium required only $2.5 \mathrm{~h}$. The time course of ${ }^{14} \mathrm{CO}_{2}$ release by both species is shown in Fig. 1.

\section{Enzymes specific for each pathway}

The above experiments suggested that at least two pathways for glutamate fermentation were used by $F$. varium, since both $\left[1-{ }^{14} \mathrm{C}\right]$ - and $\left[5-{ }^{14} \mathrm{C}\right]$ glutamate were decarboxylated to produce ${ }^{14} \mathrm{CO}_{2}$. To test for the presence of the 4-aminobutyrate pathway, a cell-free extract of $F$. varium was assayed for the presence of 4-hydroxybutyrate dehydrogenase and acetyl-CoA: hydroxybutyrate-CoA transferase. Low levels of both were detected. The optimal $\mathrm{pH}$ for both reactions was 6.5 , and the Michaelis constant $\left(K_{\mathrm{m}}\right)$ was $1 \times 10^{-3} \mathrm{M}$ for the oxidation of 4-hydroxybutyrate, whereas the $K_{\mathrm{m}}$ for its conversion to 4-hydroxybutyrate-CoA was $6 \times 10^{-4} \mathrm{M}$. To determine which pathway led to the decarboxylation at C-5 of glutamate, cell-free extracts were screened for
Table 1. Comparison of the properties of glutamate catabolic enzymes of $F$. nucleatum and $F$. varium

GDH. Glutamate dehydrogenase; ORG, 2-oxoglutarate reductase; MA, 3-methylaspartase: HBD, 4-hydroxybutyrate dehydrogenase; HT, acetyl-CoA : hydroxybutyrate-CoA transferase.

\begin{tabular}{|c|c|c|c|c|}
\hline Species & Enzyme & Coenzyme & $\underset{\text { optimum }}{\mathrm{pH}}$ & $\begin{array}{l}\text { Specific activity* } \\
{\left[\mu \mathrm{mol} \mathrm{min}^{-1}\right.} \\
\left.(\mathrm{mg} \text { protein })^{-1}\right]\end{array}$ \\
\hline \multirow{10}{*}{ F. nucleatum } & \multirow{2}{*}{ GDH } & $\mathrm{NAD}^{+}$ & $9 \cdot 0$ & $34 \cdot 0$ \\
\hline & & $\mathrm{NADP}^{+}$ & $9 \cdot 0$ & $1 \cdot 0$ \\
\hline & \multirow[t]{2}{*}{ GDH } & NADH & $7 \cdot 5$ & $16 \cdot 0$ \\
\hline & & NADPH & $7 \cdot 5$ & $1 \cdot 0$ \\
\hline & \multirow[t]{4}{*}{ OGR } & NADH & $9 \cdot 0$ & $28 \cdot 0$ \\
\hline & & NADPH & $9 \cdot 0$ & $2 \cdot 5$ \\
\hline & & $\mathrm{NAD}^{+}$ & $7 \cdot 5$ & $15 \cdot 0$ \\
\hline & & $\mathrm{NADP}^{+}$ & 7.5 & $0 \cdot 02$ \\
\hline & MA & - & - & 0.0 \\
\hline & HBD & $\mathrm{NAD}^{+}$ & - & $0 \cdot 0$ \\
\hline \multirow[t]{7}{*}{ F. varium } & \multirow[t]{2}{*}{$\mathrm{GDH}$} & $\mathrm{NAD}^{+}$ & $10 \cdot 5$ & $20 \cdot 0$ \\
\hline & & NADH & $8 \cdot 5$ & $10 \cdot 0$ \\
\hline & \multirow[t]{2}{*}{ OGR } & NADH & $9 \cdot 5$ & $18 \cdot 0$ \\
\hline & & $\mathrm{NAD}^{+}$ & $8 \cdot 5$ & $9 \cdot 7$ \\
\hline & MA & - & 9.5 & $3 \cdot 4$ \\
\hline & HBD & $\mathrm{NAD}^{+}$ & $6 \cdot 5$ & 0.2 \\
\hline & HT & $\begin{array}{c}\mathrm{CoA}+ \\
\mathrm{ATP}\end{array}$ & $6 \cdot 5$ & $0 \cdot 06$ \\
\hline
\end{tabular}

* Values are means of three experiments.

Table 2. Distribution of enzymes representative of glutamate catabolic pathways

GDH, Glutamate dehydrogenase; ORG, 2-oxoglutarate reductase; MA, 3-methylaspartase; HBD, 4-hydroxybutyrate dehydrogenase; HT, acetyl-CoA:hydroxybutyrate-CoA transferase. Enzyme specific activities of $<0.001 \mu \mathrm{mol} \mathrm{min}^{-1}(\mathrm{mg} \text { protein })^{-1}$ were considered negative.

\begin{tabular}{lccccc}
\hline \hline \multicolumn{1}{c}{ Species } & GDH & OGR & MA & HBD & HT \\
\hline F. nucleatum & + & + & - & - & - \\
F. alocis & + & + & - & - & - \\
F. gonidiaformans & + & + & - & - & - \\
F. naviforme & + & + & - & - & - \\
F. necrophorum & + & + & - & - & - \\
F. necrogenes & + & + & - & - & - \\
F. periodonticum & + & + & - & - & - \\
F. russii & + & + & - & - & - \\
F. sulci & + & + & + & - & - \\
F. ulcerans & + & + & + & - & - \\
F. varium & + & + & + & + & + \\
F. mortiferum & + & + & + & + & + \\
\hline \hline
\end{tabular}

enzymes representing both the mesaconate and 2-oxoglutarate pathways. Cell-free extracts of $F$. varium possessed 3-methylaspartase activity with an optimal $\mathrm{pH}$ of 9.5. The $K_{\mathrm{m}}$ for the deamination of 3-methylapartate was $1.6 \times 10^{-4} \mathrm{M}$. In addition, high levels of glutamate dehydrogenase and 2-oxoglutarate reductase were detected in the cell-free extracts indicating the presence of the 2-oxoglutarate pathway. The $\mathrm{pH}$ optimum for 
(a) 2-Oxoglutarate pathway
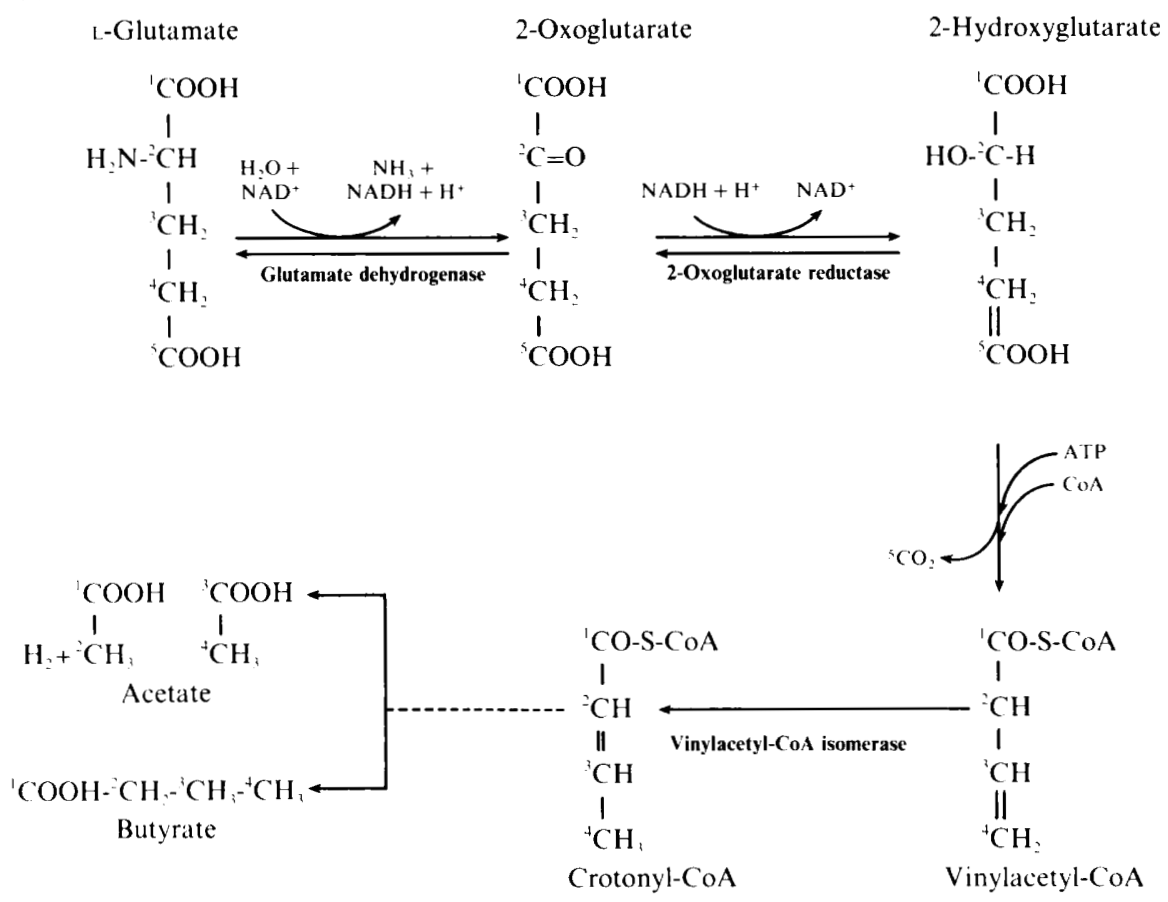

(b) Mesaconate pathway

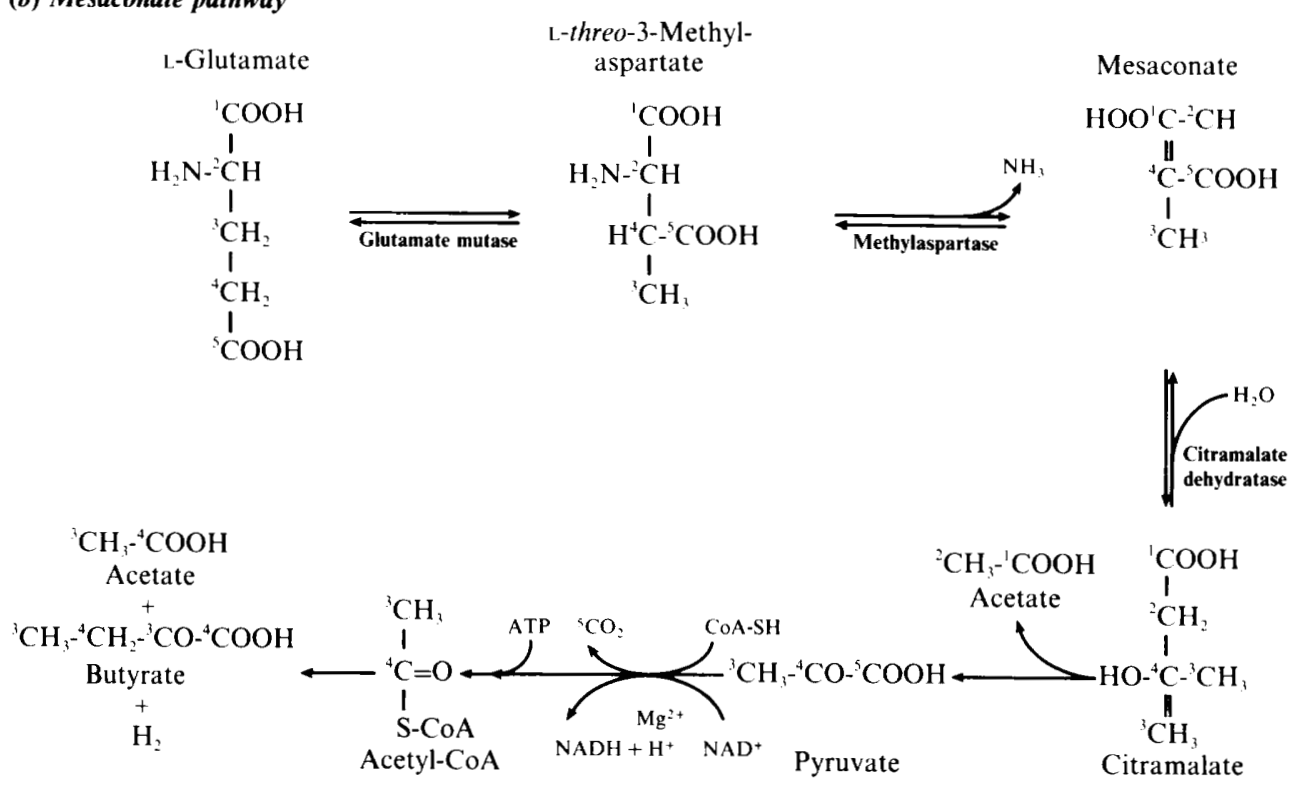

Fig. 2. Glutamate catabolism via $(a)$ the 2-oxoglutarate pathway, $(b)$ the mesaconate pathway and $(c)$ the 4-aminobutyrate pathway.

glutamate oxidation was $10 \cdot 5$, and $\mathrm{pH} 9.0$ for the reverse reaction. The reduction of 2-oxoglutarate occurred within a narrow alkaline $\mathrm{pH}$ range $(8 \cdot 0-10 \cdot 5)$ with an optimum at 8.5 . The $K_{\mathrm{m}}$ value for 2-oxoglutarate reduction was $3.26 \times 10^{-5} \mathrm{M}$, and $1.8 \times 10^{-5} \mathrm{M}$ for glutamate synthesis.
$F$. nucleatum possessed higher levels of both glutamate dehydrogenase and 2-oxoglutarate reductase than $F$. varium. The optimum for glutamate oxidation by glutamate dehydrogenase was $9 \cdot 0$, while glutamate formation from 2-oxoglutarate in the presence of $\mathrm{NH}_{4} \mathrm{Cl}$ had a $\mathrm{pH}$ optimum of 7.5. The reduction of 2-oxo- 
(c) 4-Aminobutyrate pathway
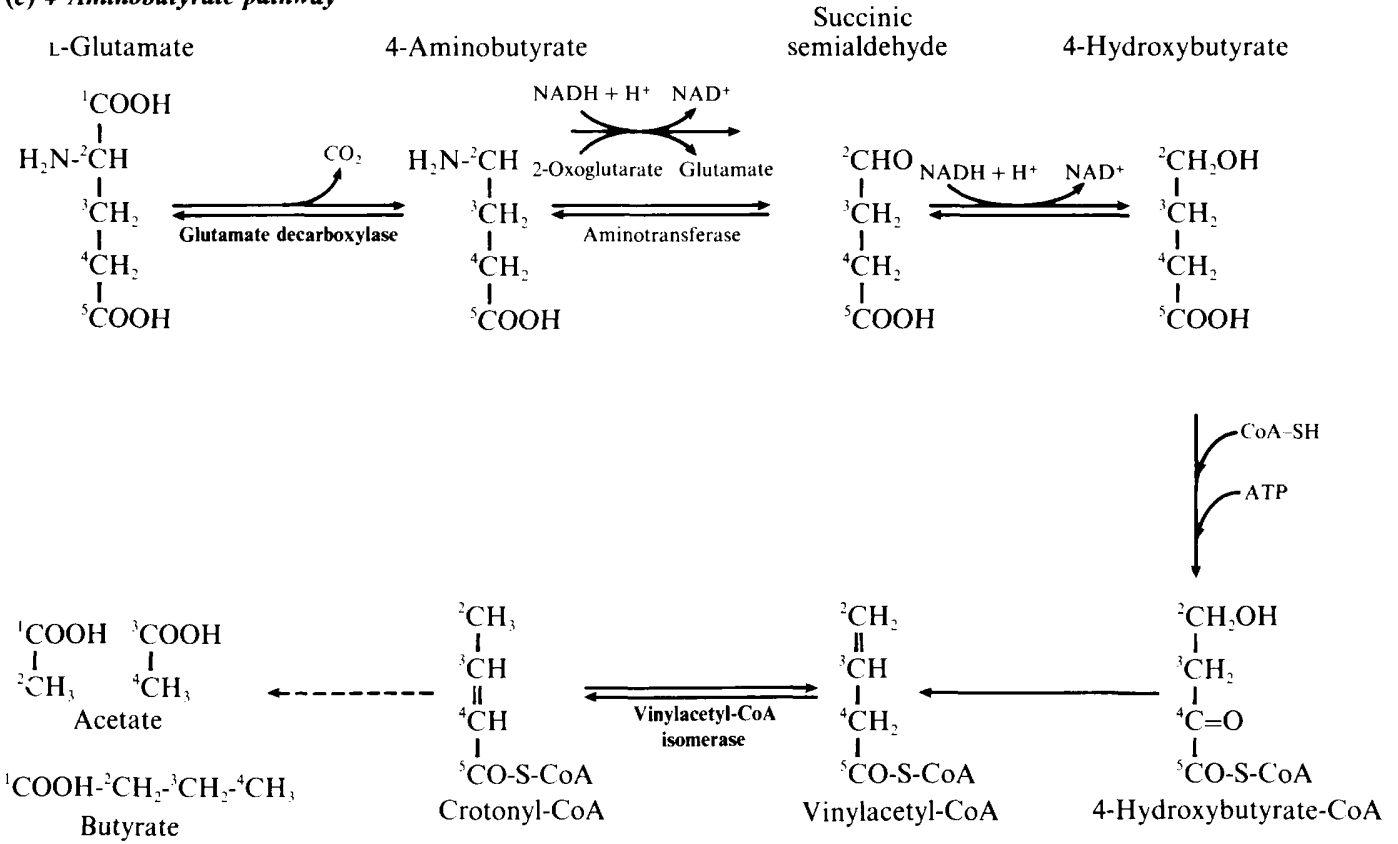

Succinic

semialdehyde 4-Hydroxybutyrate

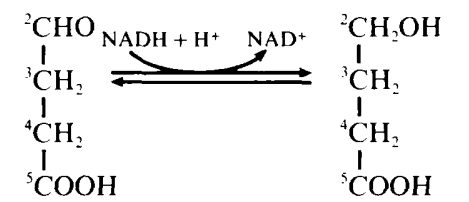

Fig. 2. (continued)

glutarate to 2-hydroxyglutarate had an optimum at $\mathrm{pH} 9 \cdot 0$. The Michaelis constant for glutamate formation was $4.7 \times 10^{-3} \mathrm{M}$, and for 2-oxoglutarate reduction in the presence of NADH, $5.3 \times 10^{-5} \mathrm{M}$. However, none of the enzymes representative of the mesaconate or the 4-aminobutyrate pathways were detected in $F$. nucleatum. The properties of these enzymes in $F$. nucleatum and $F$. varium are summarized in Table 1 .

When the type strains of other Fusobacterium species were screened for the presence of enzymes representative of the three pathways, three patterns were revealed (Table 2). $F$. mortiferum was similar to $F$. varium in possessing all three pathways, while $F$. sulci and $F$. ulcerans lacked enzymes of the 4-aminobutyrate pathway. All other strains tested possessed enzymes of the 2-oxoglutarate pathway only.

\section{Discussion}

Different pathways for the anaerobic and aerobic metabolism of glutamate have been postulated. Anaerobic bacteria generally ferment glutamic acid to acetate, butyrate, $\mathrm{NH}_{3}, \mathrm{CO}_{2}$ and $\mathrm{H}_{2}$ (Barker, 1981). The fact that anaerobes produce only $1 \mathrm{~mol}$ of $\mathrm{CO}_{2}$ per mol of glutamate degraded, whereas aerobes theoretically produce 3 mols of $\mathrm{CO}_{2}$ using the tricarboxylic acid cycle, suggests that a different pathway is used for the metabolism of glutamic acid. Several studies have been done to determine the possible pathways of glutamate catabolism in anaerobic bacteria (see, e.g., Buckel \&
Barker, 1974). Both Clostridium tetanomorphum and Peptostreptococcus aerogenes were studied extensively, and although both decarboxylate glutamate at position C-5 and produce acetate and butyrate, different metabolic intermediates were recovered (Buckel \& Barker, 1974; Lerud \& Whitely, 1971; Whitely, 1957). In the present study, $F$. nucleatum decarboxylated glutamate at C-5, possessed enzymes of the 2-oxoglutarate pathway (Fig. $2 a$ ) and lacked key intermediates of the mesaconate pathway (see Fig. 2b). F. varium, however, possessed key intermediates of both pathways, but in addition decarboxylated $\left[1-{ }^{14} \mathrm{C}\right]$ glutamate, indicating the presence of the 4-aminobutyrate pathway (Fig. 2c).

All species tested in the present study possessed high levels of both glutamate dehydrogenase and 2-oxoglutarate reductase, indicating that the 2-oxoglutarate pathway for glutamate catabolism predominates among Fusobacterium species. Several studies have been done to determine the role and distribution of this pathway among glutamate-fermenting anaerobes (Buckel \& Barker, 1974; Lerud \& Whitely, 1971; Horler et al., 1966). Acidoaminococcus fermentans, Micrococcus aerogenes and Peptostreptococcus aerogenes degrade glutamate solely via this pathway, in which the successive intermediates are 2-oxoglutarate, 2-hydroxyglutarate and probably vinylacetyl-CoA and crotonyl-CoA (Fig. $2 a$ ). The latter is converted to acetate, butyrate and $\mathrm{H}_{2}$. Although several studies were undertaken to purify the intermediates of this pathway, the enzyme responsible for the conversion of 2-hydroxyglutarate to crotonyl-CoA 
via vinylacetyl-CoA still requires investigation. Studies by Buckle \& Barker (1974) suggested a role for a dehydratase which required the presence of coenzyme-A and acetyl phosphate. In addition pre-incubation with $\mathrm{NADH}, \mathrm{FeSO}_{4}, \mathrm{MgCl}_{2}$ and dithiothreitol under anaerobic conditions was necessary to attain maximum activity. More detailed analysis requires purification of this enzyme and synthesis of the intermediates of the 2-oxoglutarate pathway.

The 4-aminobutyrate pathway interacts with the 2oxoglutarate pathway in that both require glutamate dehydrogenase for the initial reaction and use the same enzymes for conversion of vinylacetyl-CoA (Fig. 2c). The 4-aminobutyrate pathway was detected only in $F$. varium and $F$. mortiferum, both of which are normally isolated from the gastrointestinal tract.

Enzymes representative of the mesaconate pathway (Fig. 2b) were detected in the cell-free extract of four species (Table 2). The properties of 3-methylaspartase (the key enzyme for this pathway) were investigated in $F$. varium. 3-Methylaspartase had an alkaline $\mathrm{pH}$ optimum, similar to that of glutamate dehydrogenase and 2-oxoglutarate. In the initial coenzyme- $B_{12}$-dependent reaction, the linear carbon chain of glutamate is rearranged to the branch-chain of 3-methylaspartate (Fig. $2 b$ ). Elimination of $\mathrm{NH}_{3}$ plus addition of $\mathrm{H}_{2} \mathrm{O}$ yields citramalate, which subsequently is cleaved to acetate and pyruvate. The reducing equivalents produced by the subsequent oxidative decarboxylation of pyruvate to $\mathrm{CO}_{2}$ and $\mathrm{CoA}$ are used either to synthesize butyryl-CoA from 2 molecules of acetyl-CoA or to form molecular hydrogen. ATP is generated from the thioester, probably via an acyl phosphate.

A good method to differentiate between the 2oxoglutarate and the mesaconate pathways should be by the pattern of labelled end-products derived from the fermentation of $\left[{ }^{14} \mathrm{C}\right]$ glutamate. According to Fig. $2(a, b), \mathrm{C}-1$ of glutamate should be incorporated into acetate and butyrate in the 2-oxoglutarate pathway, but into acetate only in fermentation via the mesaconate pathway (Buckel \& Barker, 1974). This can be tested on the basis of the differential labelling patterns of the butyrate obtained with $\left[4-^{14} \mathrm{C}\right]$ glutamate. Butyrate formed via this pathway will be derived from $\mathrm{C}-1$ and C-3 (Fig. 2b), whereas butyrate formed via 2-oxoglutarate will be labelled at $\mathrm{C}-4$. Future studies will aim to use $\left[4-{ }^{14} \mathrm{C}\right]$ glutamate to test the relative contribution of each pathway to glutamate catabolism in $F$. varium and related species.

The results of this study reveal that glutamate is used as an energy source by all the Fusobacterium spp. tested, that is by species found in the oral cavity and in the colon of man and animals. Whereas there is no ecological distribution of species based on the pathway by which glutamate is catabolized, a chemotaxonomic grouping of species is clearly evident. Thus species such as $F$. varium, $F$. mortiferum, $F$. ulcerans and $F$. sulci that possess a peptidoglycan structure based upon diaminopimelic acid have two or three pathways for glutamate catabolism (Table 2). The remaining species, which have a lanthionine-based mucopeptide (Gharbia \& Shah, 1990), metabolize glutamate solely by the 2-oxoglutarate pathway (Table 2). The conjecture that this may reflect phylogenetic differences between these species is currently being tested by $16 \mathrm{~S}$ rRNA sequence analysis.

\section{References}

BARKer, H. A. (1981). Ámino acid degradation by anaerobic bacteria. Annual Reviews of Biochemistry 50, 23-40.

Barker, H. A., Smyth, R. D., Wawszkiewicz, E. J., Lee, M. N. \& WILSON, R. M. (1958). Enzymatic preparation and characterisation of an $\beta$-methyl aspartic acid. Archives of Biochemistry and Biophysics 78, $468-476$

Buckel, W. \& Barker, H. A. (1974). Two pathways of glutamate fermentation by anaerobic bacteria. Journal of Bacteriology 117 , $1248-1260$.

Gharbia, S. E. \& Shah, H. N. (1988a). Characteristics of glutamate dehydrogenase, a new diagnostic marker for the genus Fusobacterium. Journal of General Microbiology 134, 327-332.

Gharbia, S. E. \& ShaH, H. N. (1988b). Glucose utilisation and growth response to protein hydrolysates by Fusobacterium species. Current Microbiology 17, 229-234.

Gharbia, S. E. \& Shah, H. N. (1989). The uptake of amino acids from a chemically defined medium by Fusobacterium species. Current Microbiology 18, 189-193.

GhaRbia, S. E. \& ShaH, H. N. (1990). Identification of Fusobacterium species by the electrophoretic migration of glutamate dehydrogenase and 2-oxoglutarate reductase in relation to their DNA base composition and peptidoglycan dibasic amino acids. Journal of Medical Microbiology 33, 183-188.

Gharbia, S. E., Shah, H. N. \& Welsh, S. (1989). The influence of peptides on the uptake of amino acids in Fusobacterium; predicted interactions with Porphyromonas gingivalis. Current Microbiology 19, $231-235$

Horler, D. F., Westlake, D. W. S. \& MCConnel, W. B. (1966). Conversion of glutamic acid to volatile acids by Micrococcus aerogenes. Canadian Journal of Microbiology 12, 47-53.

LeRud, R. R. \& Whitely, H. (1971). Purification and properties of $\alpha$-ketoglutarate reductase from Micrococcus aerogenes. Journal of Bacteriology 106, 571-577.

Moore, W. E. C., Holdeman, L. V. \& Kelley, W. (1984) Genus Fusobacterium Knorr 1922. In Bergey's Manual of Systematic Bacteriology, 9th edn, pp. 631-637. Edited by N. R. Krieg \& J. C. Holt. Baltimore: Williams \& Wilkins.

RoBRISH, S. A. \& ThOMPSON, J. (1988). Suppression of polyglucose degradation by amino acids in Fusobacterium nucleatum ATCC 10953. FEMS Microbiology Letters 55, 29-34.

Robrish, S. A., Oliver, C. \& Thompson, J. (1987). Amino acid dependent transport of sugars by Fusobacterium nucleatum ATCC 10953. Journal of Bacteriology 169, 3891-3897.

ShaH, H. N. \& GHARBIA, S. E. (1989). Ecological events in subgingival dental plaque with reference to Bacteroides and Fusobacterium species. Infection 17, 264-268.

Singer, D. L. \& KLEINBERG, I. (1983). The free amino acids in human dental plaque. Archives of Oral Biology 28, 873-878.

Shah, H. N., Williams, R. A. D., Bowen, G. H. \& Hardie, J. M. (1976). Comparison of the biochemical properties of Bacteroides melaninogenicus from human dental plaque and other sites. Journal of Applied Bacteriology 41, 473-492.

Whitely, H. (1957). Fermentation of amino acids by Micrococcus aerogenes. Journal of Bacteriology 74, 324-330. 